\title{
The Poetics of Disclosure Narrating the Six-Day War in the Poetry of Nizar Qabbani
}

\author{
Professor Saddik Gohar
}

\author{
United Arab Emirates University
}

\begin{abstract}
Within defined political and aesthetic contexts, the 1967 war poetry was an attempt to redescribe and re-constitute projections of the war in Arab media and popular culture. Repudiating war and its diabolical motives, several Arab poets question and subvert a complex pattern of nationalist myths that gave rise to the 1967 war and sustained it. In this context, the paper explores the provocative war poetry of the great Arab poet, Nizar Qabbani, written in the aftermath of the 1967 war between Israel and three Arab armies. In his denial of the process that aims to obscure the war and bury its atrocities beneath cultural amnesia, Qabbanireveals narratives of trauma and pain demystifying a phenomenon that centuries of history have glorified. Within the parameters of contemporary critical theory, the central argument, in the paper, aims to interrogate the war narratives purveyed by Arab politicians and official state media and their destructive impact on collective Arab memory. The poems, investigated in the paper, aim to engage the politics and the language of war questioning the myths and the monolithic political discourse that triggered the war and paved the way for the defeat.
\end{abstract}

Keywords- War; Defeat; Arab-Israeli Conflict; Propaganda; Arab Regimes; Tyranny; Corruption; Narratives of Trauma.

\section{INTRODUCTION: CENTRALIZING THE DEFEAT}

The war poetry, analyzed in the paper, is implicated in the dominant political and cultural debates following the 1967 defeat $^{\mathrm{i}}$. In this context,Qabbani denounces the establishments which sustained the 1967 war dismissing the cultural myths ${ }^{\text {ii }}$ that paved the way for the war and reinforced it. Resisting attempts by state-side media to obscure the war memories and / or oversimplify the defeat, Qabbani reveals the false representation of the 1967 war to the public opinion reflecting the crisis of reception which occurred by the end of the war and the desire of the regimes to contain the catastrophic consequences of the defeat by focusing on what is called "imperialistic intervention". Taking into account the controversy over the 1967 war in popular circles and the diversity of perspectives raised by politicians, it is noteworthy to mention that the poetic response to the war was complex, multilayered and multi-vocal.

Introducing a tale of defeat the Arab political establishments seemed reluctant to heariii, Qabbani repudiates the war and its political motives resisting the de-historicizing process which attempted to obscure the war and its consequences. On this basis Qabbani promotes a poetics of disclosure ${ }^{\text {iv }}$ which aimed to keep the painful memory of the 1967 defeat alive in the Arab collective consciousness. Equating between the 1967 war and similar catastrophes in ancient Arab-Islamic history ,Qabbani recalls the collapse of the Islamic empire in Andalusia in the fifteenth century . Incorporating significant historical episodes as inter-texts ${ }^{\mathrm{v}}$, Qabbani illustrates that the major reason for the fall of Granada , the last Kingdom in Islamic Spain, was the conspiratorial policy advocated by the Muslim rulers against each other. In ancient Spain, the Islamic empire collapsed when Muslim and Arab rulers were divided signing treaties with their enemies against the interests of their Muslim brothers. Comparing the past with the present and drawing an analogy between the fall of Granada and the occupation of Jerusalem ${ }^{\mathrm{vi}}$, Qabbanivii argues that what happened in the Arab world during the 1960's was "a second version of the history of defeat in Andalusia." (Qabbani1993 : 312).

In several poems, censored in the Arab world, the great Syrian poet, Nizar Qabbani enumerates the reasons of the 1967 defeat linking it to a variety of cultural, social and

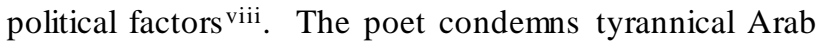
regimes who are responsible for the war and the defeat . According to Qabbani, Arab regimes are accused of deceiving their peoples with tales of false heroism and empty rhetoric during the years of mobilization that preceded the war. Therefore, the poet insists on keeping the wounds of the defeat open for public debate. In a related context, he denounces the rulers of the Arabpetroleum countries who squandered the natural resources of their people ignoring the plight of the Palestinian refugees subjected to displacement and dispersion as a result of wars against Israeli which have no strategic aims. In his war poetry, Qabbani points out that dictatorial Arab regimes willingly engaged in wars with Israel in order to camouflage internal economic and 
social catastrophes. Thus ,Qabbani urged the Arab masses to get out of the labyrinth of submission and ignorance and confront the forces of corruption supported by the ruling regimes: "do not curse the heavens / if they have abandoned you, do not curse circumstances/ for God grants victory to whom He will" (Khouri / Algar 1974 : 183).

Being aware of the dangers of the glorification of war in Arab culture, Qabbani attempts to demolish myths which portray engagement in the holy war / Jihad as a sign of Arab / Muslim moral superiority. Explicitly, the refusal of the Arab public opinion to come to terms with the 1967 warix is due to fixed concepts about the impossibility of defeat planted in collective memories by state-side media apparatuses during the pre-war years. Therefore, Qabbani's poetry seeks to dismantle the historical attempts to obscure war resisting collective amnesia which amounts to a denial of responsibility and history. Denouncing tyrannical Arab rulers who failed to defend their countries in a war which they sought, Qabbani's poetry becomes reflection of the frustration and disappointment of a generation shattered by defeat after being deceived by the false dream of Arab unity and nationalism

In spite of the atrocities and horrors of the war, Arab poets, since ancient times, have written epics glorifying war and its heroes identifying them with positive moral and cultural ideals. Some poets even run the risk of endowing herois $m$ to historical figures who demonstrated brutality in war. Nevertheless, Qabbani does not give expression to the same heroic mode. Instead, he condemns the Arab policies which paved the way for the 1967 war demystifying a phenomenon that centuries of history have glorified. Due to its crippling effect on the psyche of an entire generation of Arab intellectuals, the defeat in 1967 war transforms the famous Syrian poet Nizar Qabbani - in a single moment- from a poet dedicating his poetry to romantic and sexual issues into a poet "writing with a knife". Therefore most of his post 1967 war poetry was highly critical of the policies of Arab governments and the indifference of the Arab people toward these policies.

In Arabic cultural history and folklore, there are several epics which glorify war and its heroes identifying them with positive tribal values and moral ideals well-known in Bedouin traditions. The Arabian community in the preIs lamic and early Islamic eras war dominated by tribal wars and Arab-Arab conflicts which gave rise to a war tradition reflected in narratives about the famous Dahesand al-Ghabraa pre-Islamic war erupting as a result of tribal conflicts over pastures and water sources in the Arabian desert . Moreover, there are other folklore epics depicting the adventures and heroism of popular folklore heroes such as Antara ${ }^{x}$, Abu Zayed al-Hilali and Sayf Ben Ziyazan. War is also glorified in Islamic discourse particularly in the text of the holy Quran as a kind of Jihad against the invaders of the domain of Is lam (Deyar al-Islam) and as a struggle for survival in the hostile environment of Arabia at the rise of Islam.

In Islamic cultural mythology, those who are killed in a just war against the enemy are considered martyrs who are immediately transferred to live in paradise together with saints and prophets enjoying the pleasure of being married to the holy inhabitants of paradise - the beautiful houri. Taking this heritage into account, classical Arab poets ignore the atrocities and horrors of war endowing heroism to Arab warriors even in poems which aim to demonstrate the atrocities of war. On this basis, it becomes obvious that the task of shuttering the holy war mythology, deeply rooted in Arab cultural and religious history is a mission impossible, however, Qabbani had the initiative of confronting a war tradition which lasted for centuries . As an ex-diplomat, Qabbani has a sharp insight into the ways through which wars are falsely projected in popular culture and mythology for the sake of achieving dubious political objectives ${ }^{\mathrm{xi}}$. Engaging the pervasive representation of war from an official political perspective, Qabbani attempts to expose the real reasons for the Arab defeat in 1967 war. In his effort to demolish a pattern of myths and undermine attempts to view the defeat as result of imperialistic intervention, he identifies the vicious and immoral policies undertaken by the regimes that lead to the defeat.

The Representation of the 1967 War : An InterTextual Approach

The use of socio-historical details in addition to narratives rooted in Islamic / Christian heritage and popular mythology in the war poetry of Qabbani brings to the forefront the issue of inter-textuality as an aspect of a trans-cultural literature ${ }^{x i i}$ that transgresses linguistic and religious boundaries as well as disciplinary barriers. From a theoretical perspective, intertextuality designates vast and undefined discursive spaces and it is a way to "dissipate the many ambiguities and errors such as those brought alone in the wake of the notion of influence" (Guillen 1993: 244). Further, Jay Clayton and Eric Rothstein point out that in modern critical canons, the premise of influence contingent upon the author or authorial intentions and background is substituted by the concept of inter-textuality (Clayton \& Rothstein 1991: 3).

Theoretically speaking, the term inter-textuality was introduced for the first time in 1929 by Mikhael Bakhtin, in his book Problems of Dostoevsky's Poetics, which contains a collection of essays. The concept was developed in 1981 in Bakhtin's study The Dialogic 
Imagination where he argues that the functional text is a hybrid entity, not a single whole, it is a composite amalgamation of a variety of formulae (Bakhtin 1981: 76). Bakhtin's argument in The Dialogic Imagination advances the theory of inter-textuality underlying the existence of a dialogue between the writer and early writers not just between texts as subsequent theoris ts such as Roland Barthes seemed to think. At the core of Bakhtin's theory lies an equation between a writer and other writers, a text and other texts in addition to a kind of human participation integral to the dialogues taking place between writers.

In addition to the aforementioned argument, intertextuality is a two-sided issue and the inter-textual explication of a contemporary text with references to an old one should illuminate both texts because the knowledge of the old text supplements the understanding of its contemporary counterpart. Thus, prior knowledge of both texts are central for the reader in order to create analogies and bring to focus parallel connections and common issues. Therefore, it is convenient to compare a text, for explicatory purposes, with other texts by the same author or other authors from the present or the past taking into consideration inherent affinities and intertextual comparisons. On this basis, Jonathan Culler identifies inter-textuality as a literary technique dealing with specific analogies and establishing linkages between texts:

Inter-textuality is less a name for a work's relation to particular prior texts than a designation of its participation in the discursive space of a culture. Study of inter-textuality is not the investigation of sources and influences as traditionally conceived, it casts its net wider to include anonymous discursive practices, codes whose origins are lost, that make possible the signifying practice of later texts" (Culler 1981: 103).

In a related context, Roland Barthes identifies the literary text as network of "multiple writings" which come from a variety of sources and discourses already in circulation in some form or other. To him, the writer is a synthesizer who deliberately reworks and echoes other texts because "the text is a tissue of quotations drawn from the innumerable centers of culture" (Barthes 1977: 146). Moreover, an inter-textual study of two texts or more in terms of their allusive connections may not always lead to a full understanding. Thus, the domain of inter-textuality extends beyond the limits of time, place, acquaintance, allusions and influence. The inter-textual closeness between a text and another may be determined by their exploration of similar issues, projection of identical motifs, portrayal of similar characters, depiction of parallel situations and treatment of common problems. As expression of resembling themes, the texts, approached from an inter-textual perspective, may be close or remote in time and place and the authors may or may not have alluded to or influenced by or even heard about each other. According to Paul Ricour ," each text is free to enter into relation with all the other texts which come to take the place of circumstantial reality referred to by living speech. This relation of text to text engenders the quasi-world of texts of literature" (Ricour 1981: 149). Apart from the diversity of perspectives on the issue of inter-textuality, mentioned above, it is relevant to argue that T.S. Eliot was a precursor of the theory of intertextuality. As an advocate of allusiveness and intertextuality, Eliot, in "Tradition and Individual Talent", underlines the temporal relationship of one writer with other writers and of one text with others. Eliot argues that the literary heritage of nations forms an organic whole and no single poet is able to make a complete meaning alone because his / her genius is the result of other works: "the most individual parts of work may be those in which the dead poets, his [her] ancestors, assert their immortality most vigorously" (Eliot 1972: 71). Therefore, poets should work within tradition described by Eliot in "The Function of Criticism" as paradigms or "systems in relation to which, individual works of individual artists have their significance" (Eliot 1972: 77). In "Dialogue with an Arab Who Lost His Horse", Qabbani attributes the 1967 defeat not only to strategic / military failure but also to internal factors deeply rooted in Arab cultural traditions and history. The poet extensively uses ancient Arab and pre-Islamic narratives as inter-texts in order to link the past with the present and condemn Arab / Islamic traditions and the state of moral stagnation integral to Arab deterioration and defeats .

Associating Arab backwardness and cultural decadence to rotten traditions and tribal heritage of conflict and hostility, Qabbani states : "since the seventh century / we have been living outside the platforms of history / outside the map of the world / waiting for Antara al-Absi / who may come on the back of a white horse / to put an end to our misery / and defeat our enemies" (Qabbani $\left.1993: 218^{x i i i}\right)$. The allusions tothe folklore adventures of Antara, the pre-Islamic, black Arabian hero who achieves massive victories over his enemies in the desert, is a reference to the existence of a pattern of superstitions and false heroism dominating the Arab collective memory. Moreover Qabbani severely lampoons dictatorial Arab leaders and tyrannical regimes who launched brain-washing campaigns through media in order to conceal the destructive consequences of the 1967 
war. Demonstrating that the Arab rulers talk too much and do nothing, Qabbani dismisses the empty rhetoric phenomenon rooted in Arab traditions: "we have been talking since the seventh century / and doing nothing" (Qabbani 1993 : 217).

Denouncing Arab cultural mythologies and beliefs, Qabbani questions Islamic narratives and radical religious discourse : "we have been devouring sermons of religious fanaticism" for decades. Qabbani also criticizes a nation dominated by illusions and superstitions : " we go to bed at night / with the satirical verses of Jareerxiv in our minds" and "we wake up in the morning shedding the tears of al-Khansa' xv" ( Qabbani 1993 : 218). Qabbani argues that the Arab people are feeding on the superstitions of the past to escape from the miserable reality of successive defeats on all levels military, political, economical, social and moral . Explicitly , the 1967 defeat forced the poet to make a revision of the entire Arab history using the stories of "Jareer" and "al-Khansa' " as inter-texts to explore the contemporary political situation in the Arab world. While Jareer, the famous Arab poet devoted his life to write satirical poems lampooning rival tribes, al-Khansa', a female Arab poet, wrote elegies lamenting the death of her brothers killed in tribal wars. Alluding to ancient history and linking the past with the present ,Qabbani criticizes Arab-Arab conflicts and the state of disintegration integral to the Arab world in the 1960's. In order to underline his argument, Qabbani refers to the famous pre-Islamic war between the two tribes of "Dahes" and "al-Ghabra'" which water sources and oases in the desert.

In "Dialogue with an Arab Who Lost His Horse" Qabbani integrates folklore and popular culture elements to as inter-texts to explore the crises of contemporary Arab society.according to the poet, the Arab people in times of war and defeat, are preoccupied with superficial commitments and trivial activities wasting their time recalling "the Jokes of Johaxvi". Further, Qabbani's satirical references in -"Dialogue with an Arab Who Lost His Horse"- to "the Najd desert" and "SouqOkaz" or "Okaz Market" aim to criticize particular traditions in contemporary Arab culture by evoking historical narratives and ancient events . The reference to "Najd" is a reminder of the royal Saudi family, a symbol of dictatorial Arab monarchies in modern times . "Najd" is also associated with the historical cooperation between the founder of the Saudi kingdom, King Abdul Aziz AlSaud and Mohamed Ibn Abdul-Wahhab who established the Wahhabi Movement, the most radical Islamic institution and one of the primary sources of Islamic fundamentalism in the Middle East. It is known that the union between Saudi Wahhabism and the Egyptian
Muslim Brothers Movement in the 1950's gave rise to a variety of Islamic currents advocating political Islam and culminating in radical organizations like al-Qeda, Hammas and Islamic Jihad.

In addition to the cultural and tribal connotations associated with "Najd", Qabbani'sreferences to "the desert of Najd" allude to the negative attitude of the rulers of some oil-producing countries toward the plight of the Palestinians. Besides, the allusion to "Souk Okaz"Okaz Market is central to Qabbani's denunciation of Arab culture. "Souk Okaz" refers to a huge market held in the holy city of Mecca where merchants, poets , tribal leaders and people in general, from different parts in preIslamic Arabia meet occasionally for commercial and cultural purposes. In "Souk Okaz" people sell and buy goods and commodities including the statutes of preIslamic gods and idols. In the same occasion "Souk Okaz" , poets from the Arabian desert participated in poetic competitions and panels near the holy shrine - alKaba- and the winning epics were hanged on the walls of al-Kaba, the most sacred place for the Muslim people since the rise of Islam. Apparently, the reference to "Souk Okaz" aims to castigate the empty rhetoric and polemics of Arab politicians which is similar to the poems, composed and delivered by poets from rival tribes in pre-Is lamic Arabia ${ }^{x v i i}$.

Moreover, the references to the pagan society of Arabia , prior to the rise of Islam, including tribal wars, corruption, violence ${ }^{\mathrm{xviii}}$, fanaticism and rituals of polytheism are evoked to symbolize the state of contemporary fragmentation signifying the current situation in the Arab world where Arab tribes (countries) fight rival tribes (countries). Besides, the allusions to the worshipping rituals in ancient Arabia and the references to " the statutes of pre-Islamic gods and idols" is highly significant within the religious / political symbolism of the poem. Historically, many of these statutes were made from dates and when the Arabian Bedouins became hungry, they devoured the sacred statutes of their deities. Qabbani utilizes this historical narrativeas a metonymy indicating that fossilized Arab rulers who are transformed into idols and demigods as a result of staying in power for decades will inevitably be eradicated by their frustrated people. Finally ,Qabbani incorporates the "Souk Okaz" motif as an objective correlative to delineate the political scene in the Arab world where hegemonic regimes and conflicting governments participated in the current state of backwardness pulling their nations backward toward the ages of ignorance and darkness.

Denouncing the deception campaigns masterminded by the regime's agents which aim to mystify the 1967 war through the empty, inflammatory rhetoric of corrupt 
politicians and hypocritical religious preachers, Qabbani, points out : "if I were given authority in my homeland / I will pull out the teeth of all the Friday sermons preachers in our mosques / I will cut the fingers of all the hypocritical clowns / of all the writers who write to entertain the caliph / I will whip the opportunists and profiteers / who run after a dinar or a bowl of soup" (Qabbani 1993 : 221). Challenging hypocrisy, superstitions, and religious polemics, Qabbani calls for the eradication of the forces of darkness and fundamentalis $m$ in the ASrab world. To Qabbani, "the word" - language - in the Arab world, has been misused by politicians, religious leaders, poets and singers who turn into trumpets for the caliphs (the dictatorial regimes). "The word" in the Arab world, does not say the truth but it becomes a means of dominating the people and keeping them blind to the bitter realities of their life and the catastrophic consequences of the 1967 defeat. Politicians turn "the word" into "a monster devouring the flesh of the simple people" (Qabbani1993: 223) because Arab politics has become" a prostitution market" (Qabbani 1993 : 219).

In the Arab world and due to intermittent defeats, people escape in coffee shops listening to hypocritical singers who celebrate the defeated regimes and blaming western "imperialism" for the consequences of the 1967 war. Therefore, Qabbani cries : " if I were given the authority I will execute all the coffee shops addicts / I will chop the fingers of our singers" (Qabbani 1993 : 223). The allusion to Arab songs, sponsored by the defeated regimes, aims to highlight the vicious role played by key Arab singers, musicians and artists in the post 1967 era. Many of these singers (the hypocritical voices) actively participated in hypnotizing the feelings of the people by glorifying the dictatorial policy of the regimes and keeping the Arab people blind to the damaging impact of dangerous political predicaments and repetitive defeats . Dreaming of a future time when all the Arab "oil wells go dry" and all western- made facilities like air conditioners be removed from "the red chambers" (Qabbani 1993 : 224), of leading Arab politicians, Qabbani castigates the way of living of an elite community spoiled by extravagant petro-dollar wealth while the Palestinian refugees live in tents in isolated camps. Denouncing the repressive policy of rulers and regimes advocating western life-style while ignoring western traditions of democracy and freedom, Qabbani demonstrates : " If I have a whip in my hand / I will strip all the desert czars / of their western attires / I will strip them of their diamond rings / I will remove the paint on their fingernails / I will burn their polished shoes / and damage their golden watches/ I will force them to drink camel milk and get the saddles of their horses ready / I will force them to restore their Arab names" (Qabbani 1993 : 225). Apparently, the poet reveals that several Arab rulers descending from tribal origins have lost their identity, manhood and potency due to extravagant wealth obtained from the petrol revenues. The allusion to the "camel milk" is a call for westernized Arab rulers to regain their traditions and cultural heritage whereas the reference to "the saddles of the horses' signifies the importance of being ready to defend one's homeland against foreign invasions. Finally, Qabbani affirms that the rights of the Palestinian refugees will be restored only after "the Arab profiteers and sex brokers are castrated " and eliminated from the political scene (Qabbani 1993: 224). Qabbani also emphasizes that the Palestinian occupied territory will not be regained through poetry or singing or political rhetoric but by scarifies and struggle.

In "Waiting for Godot", Qabbani incorporates the title of Samuel Beckett's famous play as an inter-text to describe the miserable and absurd situation in the Arab world after the defeat of June 1967. According to Qabbani, Arab politicians have been waiting for Godot to liberate them from the shame of the defeat but Godot will never come. Qabbani argues that the tyrannical Arab regimes, in the post 1967 era, attempt to overcome the feeling of defeat by proliferating religious and patriotic narratives integral to ancient glories and military contributions. Qabbani points out that engaging historical victories like "the battle of Hittin" - when Saladin al-Ayyubi succeeded in defeating the crusaders terminating their reign in the East - or recalling "the battle of Badr" - when the army of the early Muslim community defeated the infidels of Mecca, will never remove the shame of the 1967 war. Qabbani also criticizes the escapist attitudes of contemporary Arab policy-makers who feed on the myths of a bygone era waiting for Godot to re-emerge from "the battle of Badr or the battle of Hittin or the sword of Saladin" (Qabbani1993 : 281).

In "A Poem of Apology to Abu Tammam", Qabbani alludes to verses from a poem written by the panegyrics master, Abu Tammam ${ }^{\mathrm{xix}}$, a well known poet in Arab / Islamic history. Qabbani aims to utilize these ancient verses in order to compare a glorious Arab past with a corrupt and defeated present .Historically, the Abbasid Caliph, al-Muta'sem defeated the Byzantine army, in the battle of "Amouriyya-Amorium " in (838) . On this occasion, Abu Tammam composed a poem dedicated to the Caliph celebrating the victory and congratulating him on this great achievement. In a poem titled "Amouriyya -Amorium ", Abu Tammam refers to the military victory of al-Muta'sem saying : " the sword speaks louder than words". Qabbani uses the preceding lines as inter-text to 
compare between ancient Arab victories and contemporary Arab defeats.

Identifying the Arab nation at present with "Ahl al-Kahf/ The Cave People" alluding to the famous Koranic narrative and the biblical legend of the "seven sleepers", Qabbani argues that due to contemporary political corruption and cultural stagnation, the Arab nation failed to achieve a single victory. Using the story of $\mathrm{Abu}$ Tammam and al- Muta'sem as objective correlative and incorporating "the seven sleepers" fable as inter-text, Qabbani juxtaposes the past to the present viewing a modern world where people are dominated by religious superstitions . Qabbani laments the spread of chaos and ignorance in the Arab world. Instead of fighting internal corruption and injustice, the Arab people implore to Islamic saints and holy figures like "Umar and Alixx" to save the Arab nation from endless catastrophes. By the end of the poem, Qabbani describes an Arab world divided by geographical barriers, ethnic differences , Arab-Arab conflicts and dominated by brutal military regimes . Criticizing local Arab rulers, the inheritors of the colonial legacyxi, who enhance the spirit of disintegration among the Arab nations, Qabbani denounced contemporary Arab politics expressing his denial and rejection of Arab culture and religion. Obsessed with feelings of defeat and humiliation, Qabbani expressed his doubts about the possibility of an Arab rebirth. In a pessimistic tone, he points out that a potential resurrection of ancient Arab glory is a farreached aspiration as long as Arab people live in a homeland predominated by superstitions and governed by dictatorial regimes.

\section{APPROPRIATING HERITAGE AND TRADITION IN QABBANI'S WAR POETRY}

In The Achievement of T.S. Eliot, F.O. Matthiessen discusses Eliot's utilization of fertility myths and rituals pointing out that Eliot succeeds in discovering that the recurring patterns in various legends are basically the same and that "the vegetation myths of the rebirth of the year, the fertility myths of the rebirth of the potency of man, the Christian story of Resurrection and the Grail legend of purification are basically the same" (Matthiessen 1958: 36). In addition to admiration of Eliot's fertility rituals and myths, Qabbani and fellow Arab poets were attracted to other aspects of Eliot's modernism. Appropriating Eliot's modernist techniques and poetic strategies to fulfill local political purposes, different from Eliot's Christian vision, Arab poets since the mid-forties have integrated Eliot's western thought into the Arabic literary canon. Instead of attempting to disrupt Eliot's works as a symbol of western Christian hegemony and colonial discourse,

Arab poets repeatedly drew the analogy between the aridity of Arab life after the 1948 disaster in Palestine and the aridity of the land in the fertility myth saved from complete waste only by death and the spelling of blood, analogies to the falling of rain over a parched land (Jayyusi 1977: 724).

In this context, Qabbani, utilized Eliot's modernist narrative not only to depict the moral bankruptcy of the Arab world in the post 1967 war era but also to criticize aspects of life in a community dominated by injustice and political corruption. Appropriating Eliot's vision of the modern world as a wasteland, Qabbani utilizes Eliot's poetic strategies incorporating allusions, symbols, myths and other forms of literary influence to articulate Arab-Arab conflicts and internal dilemmas. Unlike postcolonial poets who undermine western narratives by negating them, Qabbani does not identify western colonial texts with authority or colonial hegemony. Instead, he assimilates them into the Arabic literary tradition creating a hybridized poetics able to address the challenges of an era of defeats particularly Eliot's "idea of the cycle of sacrificial death that leads to rebirth which attracted them most" (Jayyusi 1977: 724).

Viewing a world which turns into a big prison, Qabbani, in his war poetry, argues that Arab people are powerless, hopeless, friendless and are repeatedly smashed by repressive apparatuses. Taking the risk of living in the Arab wasteland, the poet encounters a world where there is no place for freedom, democracy or equality. Here, the political regimes turn into machines crushing people then spitting them out like chaff. Those intellectuals who try to break out and revolt ${ }^{x x i i}$ against the regimes are inevitably broken and crushed. Using images of violence and harshness, in a striking way, Qabbani aims to underline the destructive principle of Arab culture and the real danger of living in the Arab wasteland. Regardless of the unfavorable images which predominate the scene, Qabbani signifies that the Arab poet has no option but to go through the risky journey across the Arab wilderness challenging the advocates of dictatorship and the forces of darkness. The pattern of imagery in Qabbani's war poetry is sufficient to reveal the poet's vision of a defeated world and a destructive culture that the poet has to challenge in order to map out the way of salvation and reform. In order to overcome the tyrannical policies of the regimes, the poet has no choice but to write a poetics of disclosure able to strip the defeated leaders of their false sanctity. 
In this context,Qabbani considers his poem "Footnotes to the Book of the Setback" as a dividing line between two stages in his poetic career. The first stage was devoted to women and feminist issues and the second stage was dominated by his commitment to resistance xxiii $^{\text {. }}$ and struggle against official Arab politics toward the Palestinian question. In this poem, Qabbani speaks about the failure of Arab policy-makers to transform the indigenous natural sources into a weapon in the battle with a ruthless enemy instead of squandering Arab wealth under the feet of prostitutes : " Our desert oil could have become / daggers of flame and fire / we are a disgrace to our noble ancestors / we let our oil flow through the toes of whores" (al-Udhari 1986 : 99) . In the preceding revolutionary poem, Qabbani aims to scandalize the Arab military regimes and their defeated armies that failed to defend the Arab homeland. He provokes Arab masses to revolt against the stagnation of a backward culture and the tyranny of corrupt regimes : " we want a generation / that does not forgive mistakes / that do not bend / we want a generation of giants "(al-Udhari 1986 : 101).

Qabbani also urges Arab people to protest ${ }^{\text {xxiv }}$ against the forces of corruption as well as the spirit of defeatism even if it is associated with holy texts : "kill the opium in our heads / kill the illusions" (101). Further ,Qabbani lampoons the absurd reality of the Arab world using the Koran as inter- text in a sarcastic manner: "Are we really the best nation on earth?". Qabbani repudiates a political system which transforms "dwarves into giants" and a culture which breeds backwardness and decadence. To him the function of poetry is "to kill the monsters" lurking in the cities of the Arab world since the tenth century devouring children, taking women as hostages and filling the nights with fear and horror. Explicitly, these monsters are backwardness, oppression and tyranny.

Due to the spirit of shock and the dis appointment born out of the 1967 war which was more damaging than the earlier defeat in 1948 , Qabbani attempted to emphasize his Arab identity and existence. Therefore, he clings to his cultural roots and religious heritage coming to terms with war and experiencing the consequences of the defeat. Since the feeling of defeat and humiliation has undermined the national identity and personal dignity of the Arab poet (Qabbani), he resorted to the past seeking refuge in Arab history and cultural traditions. Imitating Eliot's techniques and engaging western modernist theories ,Qabbani draws upon historical and religious sources evoking ancient Arab glories as manifestations of his rejection of a corrupt and defeated present.
Obviously ,Qabbani's June war poetry was not only triggered by the military defeat of the Arab armies in 1967 but it was also the result of confronting the backwardness and oppression of a stagnant society. In this context, Qabbani's war poetry becomes reflection of accumulated sadness - in Arab psyches-since the battle of

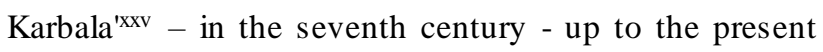
time. Using Eliot's modernist strategies, Qabbani evokes from history the painful story of Karbala in order to underline Arab-Arab conflicts and internal wars that have torn the Arab world apart. After the 1967 war, states Qabbani, poetry should be turned into a weapon, otherwise it will not survive. Dedicated to a politically committed literature, Qabbani believes that after 1967 war the process of writing poetry should be "an act of martyrdoms". To him, all the Arabic poetry, composed prior to the 1967 war, should be dumped in the dustbin of history. After 1967, the only literature that could survive is that which is written with the bullets of the Palestinian commandos (fedayeen) breaking the silence of the occupied territories. To Qabbani, a bullet in the chest of the enemy is better than all Arabic poetry.

In "A Reading on the Graves of Mad People", the speaker, in the poem, appears in a state of utter misery and frustration attempting to escape "from the cities of salt"xxi" (Qabbani 1993 : 304) and live in exilexxvii. The "cities of salt" motif is a reference and an allusion to the capital cities of the Arab world, dominated by oppression , tyranny and stagnation. Due to the military defeat in June 1967 and the occupation of Arab territories, the speaker lost his manhood and become sexually impotent. Like the figure of Alfred Prufrockin Eliot's famous poem , Qabbani's persona, a symbol of the Arab intellectual, fails to make love to his mistress : "Her body seemed strange to me / Her bed was very cold / and her breast became a withered lemon / After June I lost my sexual appetite" (Qabbani 1993 : 309). As a result of the trauma of the defeat , the poet denounced "the map of Arabism" and the slogans about Arab-hood and Arab nationalism" affirming that in every inch in the Arab world " there is a dictator and a tent".

Drawing upon Eliot's poem "The Hollow Men" which views the moral collapse of modern civilization, Qabbani portrays a similar community, a cartoon world dominated by false religion and the petro-dollar . Qabbani criticizes the state of sterility and aridity in the Arab world spotting a network of rotten traditions and perverted practices which distort morality utilizing religion as a camouflage. Denouncing "the straw and cotton Sultanates" and "the petrol Sheikhdoms" as well "the Arab tribes" scattered like "dry papers", Qabbani throws light on rituals of victimization and injustice inherited in the Arabian environment (Qabbani 1993 : 
312). In other words, Qabbani protests against a web of traditions that have marginalized women isolating them in the historical Harem. He considers these rotten traditions as one of the basic reasons that indirectly led to Arab defeats and catastrophes. Qabbani refers to a form of adultery called "the Mut'ah Marriage" or "marriage for sexual pleasure" , a short-term marriage sanctioned by corrupt Islamic preachers to allow the Arab Sultans and the rich elite in the Arab world to have sexual affairs with any number of concubines (mostly under-age) at the same time.

Apparently, this kind of marriage is considered by major Islamic sects as a form of adultery and prostitution, however, it is sanctioned by religious jurists to gratify the sexual instincts of the elite. Moreover, Qabbani incorporates Eliot's juxtaposition technique ${ }^{x x v i i i}$ utilizing the collapse of the Islamic empire in Andalusia in the fifteenth century as an inter-text illustrating that the major reason for the fall of Granada (in 1492), the last Kingdom in Islamic Spain, was the conspiratorial policy advocated by the Muslim rulers against each other. In ancient Spain, the Islamic empire collapsed when Muslim and Arab rulers were divided signing treaties with their enemies against the interests of their Muslim brothers. Qabbani argues that what happened in the Arab world during the 1960's was "a second version of the history of defeat in Andalusia." (Qabbani 1993 : 312) equating between the fall of Granada and the occupation of Jerusalem ${ }^{x x i x}$ during the 1967 war.

In "The Will / al- Wasiyya", Qabbani denounces a network of decadent Arab traditions which paved the way for the loss of Palestine and the defeat of the Arab armies in the wars with Israel : " I opened my father's box / and tore his will into pieces / I sold all my inherited traditions in auction" (Qabbani 1993 : 249). Qabbani dismissed fossilized traditions and religious superstitions which kept the Arab world backward since the early Islamic era including "Thousand Nights and One Night" narratives which participated in keeping the Arabs prey to myths and legends : "I burnt down my alphabets / I made a new alphabet made of Palestine, its defiance, its bullets and its wheat soaked in tears" (Qabbani 1993 : 252).

In "The Will", Qabbani exposes the scandalous behavior of the Arab rulers to the public opinion stripping them of their superficial sanctity. When the speaker, in the poem , was making a tour in "the caliph's harem", he "trod over the bodies of mistresses and castrated eunuchs" (Qabbani 1993 : 254) available for the gratification of the caliph's lust : "Like thunder, I entered through the caliph's window / I found him, like his predecessors seven centuries ago, sleeping with a Roman concubine / I read for him verses from the Koran about Jihad / about Prophet Mohamed and the religion of Islam", then "I said to myself / May God bless the caliph's Jihad in the breasts and the soft hands of concubines and the tits of whores" (Qabbani 1993 : 253). In a dialogue with the caliph, Qabbani sarcastically implores " His Highness" to get out of "his rosy bed-room" because he has been fossilized in the same chamber since seven centuries.

Like the ex-caliphs in the early Islamic era, modern Arab rulers live in ivory towers dealing with their subjects as a flock of sheep and cattle. In a lamentable tone, Qabbani tells the modern Arab caliph: "Our Dear prince, please get out to the streets / and try to read a daily newspaper at least / Read about the Suez Canal War , the Jordan River/ the Golan Heights and the raped cities / Read about those who crossed the Jordan River / on their way to the West Bank / Sir, do you ever have a small map of the West Bank in your palace?" (Qabbani1993 : 258). Apparently the references to the Palestinian refugees crossing the Jordan River is a reminder of the double exodus of Palestinian citizens who were forced to evacuate their "raped cities" in the West Bank during the 1948 and the 1967 wars. The allusion to the Golan Heights signifies the Israeli occupation of this strategic region, located on the borders between historical Palestine and Syria. Further, the reference to the Suez war evokes the memories of an aggressive war launched by imperialistic powers against an Arab country ( Egypt) in 1956 . During his confrontation with the Arab caliph ,Qabbani's persona indicates that some of the rulers of wealthy Arab countries have turned their backs on the radical transformations in the region. They live in another world completely unaware of the great ramifications of the military conflict in the Middle East and the consequences of the Palestinian tragedy .

\section{UNVEILING THE REALITIES OF THE 1967 WAR}

Describing backward Arab cultural traditions as a monster eating the minds and imagination of an entire nation, Qabbani displays the damaging consequences of tyranny, religious fundamentalism, sexual repression and technocracy which led to the death of the spirit. His indignation against contemporary Arab society turns his poetry into a prolonged elegy about a whole generation of optimists who were denied the fulfillment of their political and intellectual aspirations in an era of nationalism. Expressing the disillusionment of a generation who expected prosperity and reform in a postcolonial era ,Qabbani denounces the emerging regimes that failed to fulfill the aspirations of their people. After the departure of the forces of western colonization, the expected dream of Arab nationalism and unity was frustrated. According to Qabbani, the corrupt post-colonial rulers, the inheritors of the colonial 
legacy, have sold out the interests of their nations to the imperialist West in return for diabolical mutual interests . Accusing the Arab regimes of treachery, Qabbani castigates the pro-imperialist / bourgeois rulers and the reactionary forces, who support the imperialist agenda in the Middle East . Through a conspiracy between local dictatorial regimes and imperialistic countries, the western democratic world turned deaf ears to the policies of oppression and human rights violations in the Arab world .

In a famous poem entitled "When Will they Declare the Death of the Arabs?" ,Qabbani castigates the Arab official system where "tribes are fighting tribes" and where women are oppressed and human rights are denied. He laments a world where poets "are licking the feet of the Caliphs for the sake of fifty Dirhams and a handful of rice". In the same poem, Qabbani portrays communities dominated by secret police agents, where people are afraid of the regime "more than their fear of God". Qabbanialso attacks a world, governed by sword and fire where media is controlled by the regime's informers and where journalists are forced to prostitute their talents serving a corrupt system. In "When Will they Declare the Death of the Arabs?" ,Qabbani introduces an image of a bankrupt political system which plays no significant role in current international politics : "The Arab world is exhibited in a furniture auction but I did not see the Arabs" (cited in Gohar 2001 : 150).

In "A Summer Invitation for the Fifth of June", Qabbani recalls the memories of the military defeat which took place in the fifth of June 1967. Written five years after the 1967 war, on the fifth anniversary of the defeat, the preceding poem introduces the month of June in hyperbolic context whereas "June" is personified as a bare-footed man with miserable features and a face revealing 'the sorrows of heaven' and 'the pains and anguish of al-Hussein ${ }^{\mathrm{xx}}$ " (Qabbani 1993: 209). Apostrophizing June and evoking the memory of Karbala ( the greatest catastrophe in the entire Islamic history ), Qabbani addresses "the month of the defeat " sarcastically quoting Arab politicians : " we will make you forget Palestine / we will remove the trees of sadness from your eyes / we will burn the Koran / and assassinate Jesus Christ / we will give you a one-way Arab passport" (Qabbani 1993 : 212). After condemning the indifferent attitude of the Arab policy-makers toward the 1967 defeat ,Qabbani criticizes Arab cultural mythology responsible for the backwardness of the entire region. The central irony in the poem is that while Arab politicians were involved in ideological rhetoric and propaganda slogans, the agents and executioners of the regimes were writing the names of their victims on the bodies of "the belly dancers" (Qabbani 1993: 214).
In Qabbani's post 1967 war poetry, the Arab leaders appear, in an unfavorable way, as vampires who work against the interests of their people squandering national resources . In several poems ,Qabbani depicts hypocritical and corrupt Arab politicians in a humiliating manner viewing them as opportunists and profiteers blocking the way toward salvation and reform in the Arab world. Inimical to the interests of their people and in league with the reactionary forces of evil and darkness, Arab politicians attempted to prevent the Arab community from regaining its vigor and achieving advancement .In "The Governor and the Sparrow", Qabbani severely criticizes the Arab political system supported by a police apparatus specialized in the arts of brutalization and subjugation. Arab citizens, in the poem are tortured and humiliated for no apparent reasons. In "The Ruler and theSparrow", Qabbani foregrounds the policies of persecution advocated by the Arab regimes against voices of freedom and liberation in the Arab world: "I traveled in the Arab homeland/ to read my poem/ I traveled with only a notebook/police stations tossed me about/soldiers tossed me about/and all I had was a sparrow in my pocket" (Al-Udhari 1986: 103).

Depicting a homeland which is transformed into a big prison and detainees camp extending from the Arabian Gulf to the Pacific Ocean, Qabbani criticizes the aggressive attitude fostered by the ruling establishments against Arab intellectuals. In spite of carrying a sparrow , an epitome of his poetic talent, "the officer asked/for the sparrow's passport / the word in my country needs a passport" (Al-Udhari 1986: 103). Using the "sparrow" as a symbol of the free poetic word, the poet - during his imaginary tour in the Arab world - criticizes the inhuman practices of the state-side police, sponsored by the regime to tyrannize the voices of opposition. In reality Qabbani, himself, was frequently prevented from reading his poetry to the masses : "I travelled from one country to another / carrying a book of poems / but I was taken from jail to jail / beaten by brutal police operatives" (Qabbani 1993: 244).

\section{CONCLUSION: FROM THE SUEZ CRISIS (1956) TO THE OCTOBER WAR (1973)}

Prior to the 1967 war, which erupted as a result of strategic failure on the part of the Arab regimes who declared war against Israel for no reasonable reasons, Qabbani denounced the tripartite attack against Egypt. In a poem titled "A Message from a Soldier on the Suez Front", Qabbani describes the military offensive, known as the Suez War. In 1956 , three countries , England, France and Israel launched an assault on the Egyptian forces and civilians on the Suez canal region. The invasion took place primarily because of differences 
between the Egyptian government and England over political and financial issues including the future administration of the Suez Canal in the aftermath of the British withdrawal from Egypt. The Egyptian president , Nasser, was forced to nationalize the Canal Company to secure revenues required to build the Aswan High Dam- crucial to Egyptian agriculture and food securityafter the World Bank turned down an Egyptian application for a loan due to the intervention of imperialistic countries particularly England and France. But, France participated in the as sault initially because of Nasser's militarily support to the Algerian rebels in their revolution against the French occupation.

Further, Israel also took part in the war as a result of hostilities with Nasser's regime over the Palestinian / Israeli issue. The air forces and the navy ships of England and France were engaged in the war in addition to the interference of the Israel ground troops which occupied parts of the Sinai desert. The aggression against Egypt in 1956 ended in fiasco due to the failure of the invaders to recapture the Suez Canal. As a result of formidable armed resistance particularly in the city of Port Said and in response to international pressures from the Soviet Union and the United States, the forces of the three attacking countries were compelled to withdraw without achieving the strategic goals of the war. England and France failed to occupy the Suez Canal Zone and remove Nasser from power while Israel was not able to capture any parts of the Sinai Peninsula. Consequently Nasser's regime achieved a diplomatic victory and Nasser was hailed as a hero.

In Qabbani's poem, the invaders are depicted as international pirates and mercenaries with "blue eyes" and "black hearts" (Qabbani 1993: 42). Unlike other poems where Qabbani compares a backward and decadent East with a civilized West, "A Message from a Soldier" is highly critical of western imperialistic policies in the Middle East probably because the 1956 war not based on any moral ground. Since the war was motivated by colonial aspirations and the desire to keep control over an independent country leading to the death of Egyptian civilians in heavily populated cities located near the Suez Canal, Qabbani describes the attacking forces as criminals and thieves : "the highway robbers come back / climbing over our walls and threatening our existence / turning the homeland of my ancestors into inferno" (Qabbani 1993: 41).

The strategic victory, achieved by Nasser's regime in 1956 over three powerful countries increased the confidence of the regime in its military potential providing impetus which accelerated the events leading to the involvement of the Egyptian army in the civil war in Yemen in the early sixties. After the failure of the
Egyptian troops in Yemen due to their unfamiliarity with guerrilla war tactics, the regime was searching for any possible victory to compensate for the loss in Yemen. Therefore, the media war campaign against Israel was intensified after the return of the Egyptian army from Yemen. The strong Egyptian economy - at that time- was devastated beyond repair during the Yemeni war as a result of the war costs. Therefore, the regime in Egypt as well as other tyrannical Arab governments - was ready to go through new military adventures to keep the public opinion blind to the catastrophic consequences of the military interference in the war in Yemen. The regime's irresponsible war mobilization particularly the blockade of the Tiran strait in the Aqaba Gulf which put the Israeli security in jeopardy triggered the first sparks

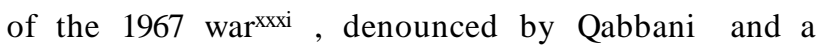
generation of Arab intellectuals.

Disappointed by the spirit of defeat - crippling the Arab collective consciousness after the 1967 war-, Qabbani attempts to give his generation some hope of a better future. Thus, Qabbani's speaker, in a poem titled "One Way", expresses his desire to carry arms and fight the enemy : "I am in dire need of a rifle / I will sell the rings of my mother and get a rifle" (Qabbani 1993 : 327). After purchasing a rifle, Qabbani's persona decides to be involved in armed resistance against the invaders: "now I have a rifle / take me with you to Palestine / I have been searching for my homeland and national identity for twenty years / I have been searching for my usurped house surrounded by electric wires" (Qabbani 1993 : 328).

In the aftermath the military victory of the Egyptian army over the Israeli forces and the crossing of the Egyptian troops of the Suez Canal barrier into Sinai in October 1973 , Qabbani temporarily regained his potency. Thus the raped homeland is metaphorically transformed into a beautiful woman making love to the poet who restores his sexual power after years of emasculation following the 1967 defeat. At a particular moment ,Qabbani expressed his wish that the October war would lead to the death of the spirit of defeat born out in June 1967 but his desire was frustrated because Arab defeats have no end. Though "June is dead", Qabbani resumes his criticism of the Arab governments responsible for an everlasting series of catastrophes and successive defeats including the Lebanese civil war and the Israeli invasion of Lebanon in 1982 resulting into the third Exodus of the Palestinian refugees. Qabbani also criticized the Iraqi / Iranian war sponsored by the oil- producing countries which only served the interests of imperialistic powers in the region. Further, Qabbani severely attacked the Iraqi invasion of Kuwait in 1990 which opened the doors of the Arab world for foreign intervention leading to the 
fragmentation of the Arab nation and reinforcing hostilities among Arab peoples.

\section{REFERENCES}

[1] Al-Udhari, Abdullah . Modern Poetry of the Arab World .Middlesex : Penguin Books , 1986.

[2] Bakhtin, Mikhael. The Dialogic Imagination: Four Essays, ed. Michael Holquist, tr. Caryl Emers on and Michael Holquist. Austin, Texas: Texas University Press, 1981.

[3] Barthes, Roland. Image, Music, Text,tr. Stephen Heath. London: Fontana, 1977.

[4] Clayton, Jay and Eric Rothstein, ed. Influence and Intertextuality in Literary History. Madison: The University of Wisconsin Press, 1991.

[5] Culler, Jonathan. The Pursuit of Signs: Semiotics, Literature, Deconstruction. Ithaca: Cornell University Press, 1981.

[6] Eliot, T.S. "The Function of Criticism", in Twentieth Century Literary Criticism, ed. David Lodge. London: Longman, 1972. PP. 77-84.

[7] __________. "Tradition and Individual Talent", in Twentieth Century Literary Criticism, ed. David Lodge. London: Longman, 1972. PP. 71-77.

[8] Gohar Saddik. "Engaging British Modernist Traditions into Contemporary Arabic Poetry". In Reflections on World Literature, Ed. Nilanshu Kumar Agarwal. New Delhi, 2009. 51-62.

[9] --------"Engaging the Cities of Exile in Modern Arabic / Palestinian Poetry". Folia Linguistica et Litteraria Vol. 314 (2011): 201-2012.

[10]----------"Exile and Revolt: Arab and AfroAmerican Poets in Dialogue". In Creativity in Exile, Ed. M. Hanne. New York: Rodopi, 2004. 159-181.

[11]------- "Frontiers of Violence and Fear: A Study of Native American and Palestinian Intifada Poetry". Nebula: A Journal of Multidisciplinary Scholarship Vol.2.3 (2005): 34-69.

[12]----------"Re-Contextualizing the Six-Day War: The Counter-Poetics of Nizar Qabbani". Middle East Panorama (Fall -2010): 1-15.

[13]--------- "Re-historicizing the Six-Day War: The Counter Poetics of Nizar Qabbani". SKASE Journal of Literary Studies Vol.3.1- (2011): 97-116.

[14]---------- "Rethinking WatariyyatLayliyya / Night Strings." Rupkatha Journal on Interdisciplinary Studies in Humanities Vol.3.4 (2011): 443-480.

[15]---------"Rewriting Islamic History in Contemporary Arabic Poetry". Romano-Arabica Vol. 8 (2011): 54-93.
[16]-------"Subverting the History of Slavery and Colonization". Western Journal of Black Studies. Vol.1 (2008): 16-29.

[17]-------"The Discourse of Exile and Displacement in Arabic and Palestinian Poetry". Hyphen: An International Journal of Interdisciplinary Studies in Literature, Art and Culture Vol. 2 (2011): 30-41.

[18] -----------"The Integration of Western Modernism in Postcolonial Arabic Literature". Third World Quarterly Vol.29.2 (2008): 375-390.

[19] -------"The Discourse of Humiliation and Shame in Qabbani's 1967 War Poetry". Middle East Mirror. (September - 2010): 1-18.

[20]-------- "The Poetics of Resistance". International Journal of Arabic and English Studies Vol.7 (2006): 5-28.

[21]------- "The Political Poetry of Le Roi Jones and Mudhafar Al-Nawwab: Comparative Perspective". Digest of Middle East Studies Vol. 15.2 (2006): 6988.

[22] -------" The Protest Poetry of Muhamad Al-Fayturi and Langston Hughes". Studies in Islam and the Middle East Vol.4.1 (2007): 1-11.

[23]-------"The Use of Eliot's Modernism in A1Sayyab's City Poetry". Comparative Civilizations Review Vol. 56 (2007): 40-55

[24]----------"The Use of Political Discourse in the Poetry of M. Al-Nawwab and Le Roi Jones: Transcultural Approach". LiCuS-Journal of Literary Theory and Cultural Studies Vol.2.3 (2007): 21-45.

[25] ----------"The Use of T.S. Eliot's Literary Traditions in Contemporary Arabic Poetry". In Chewing Over the West: Occidental Narratives in Non-Western Readings, Ed. Doris Jedamski. New York: Rodopi, 2009. 127-160.

[26]----------"Toward a Dialogue between the Arab World and the West: The City Analogy in the Poetry of T.S. Eliot and Badr Shaker Al-Sayyab". Journal of Middle Eastern and North African Intellectual and Cultural Studies Vol. 4 (2006):43-67.

[27]----------Twentieth - Century Arabic Poetry. Cairo: Oyun Press, 2001.

[28] Guillen, Claudio. The Challenge of Comparative Literature, tr. Cola Franzen. Cambridge, Mass.: Harvard University Press, 1993.

[29] Jayyusi, Salma Khadra. Trends and Movements in Modern Arabic Poetry (2 vols.). Leiden: E.J. Brill, $1977 .$.

[30] Khouri, Mounah and Hamid Algar, tr/ed. An Anthology of Modern Arabic Poetry. Berkeley: University of California Press, 1974. 
[31] Matthiessen, F.O. The Achievement of T.S. Eliot.

New York: Oxford University Press, 1958.

[32] Qabbani , Nizar . The Complete Political Works. Beirut: Nizar Qabbani Press, 1993.

[33] Ricour, Paul. Hermeneutics and the Human Sciences: Essays on Language, Action andInterpretation, ed. J.B. Thomson. London: Cambridge University Press, 1981. Notes

i See Saddik Gohar. "Re-Contextualizing the Six-Day War: The Counter-Poetics of Nizar Qabbani". Middle East Panorama (Fall -2010): 1-15.

ii See Gohar Saddik. "The Use of Political Discourse in the Poetry of M. Al-Nawwab and Le Roi Jones: Transcultural Approach". LiCuS-Journal of Literary Theory and Cultural Studies Vol.2.3 (2007): 21-45.

iii Saddik Gohar. "The Discourse of Humiliation and Shame in Qabbani's 1967 War Poetry". Middle East Mirror. (September - 2010): 1-18.

iv Saddik Gohar. "Engaging British Modernist Traditions into Contemporary Arabic Poetry". In Reflections on World Literature, Ed. Nilanshu Kumar Agarwal. New Delhi, 2009. 51-62.

v Saddik Gohar. "The Use of Eliot's Modernism in A1Sayyab's City Poetry". Comparative Civilizations Review Vol. 56 (2007): 40-55

vi Saddik Gohar. "Engaging the Cities of Exile in Modern Arabic / Palestinian Poetry". Folia Linguistica et Litteraria Vol. 314 (2011): 201-2012.

vii Nizar Qabbani was born in Damascus in 1932 in a district famous for its struggle and resistance against the French occupation troops during the era of colonization. As a young man, he married Zahra, a Syrian lady, and had two children, Tawfiq and Zahra. Then he married an Iraqi lady, Balqis, after a great love story but Balqis was unfortunately killed in an explosion which targeted the American embassy in Beirut, where she works, during the Lebanese civil war in the 1980's. Qabbani, who descended from a well-known family, in Damascus, was appointed as an ambassador after his graduation from Damascus University in the 1950's . However, he was forced to resign from his job as a result of publishing poems attacking the Arab rulers and governments after the defeat of the 1967 war. Consequently, he left his country and spent most of his life in Lebanon and Europe where he became a professional writer and poet. Most of his poetry prior to the 1967 war was devoted to the is sue of feminism and the degrading status of women in the Arab world. Originally identified as the poet of women and erotic love, his poems were censored in many Arab countries, however his poetry opened new horizons extending the boundaries of Arabic poetics and challenging conservative Arab traditions. His first anthology was published when he was a student at Damascus University and created controversy in conservative circles due to its candid treatment of the issues of sex and male / female relationship in the Arab world. His repudiation of backward and conservative Arab traditions started at an early age when he witnessed the suicide of his sister who killed herself because she was forced to be separated from her lover and marry a man she did not love. Therefore, his early poetry was a severe criticism of a male-dominated world and a challenge of the repressive policies advocated by a hegemonic patriarchal society which oppressed women. Moreover, . his political poetry, particularly his famous and provocative poems "Love and Petroleum", "Bread, Hashish and Moon" and "Margins on the Notebook of the Defeat", led to the censorship of his literary works in most of the Arab countries. Qabbani's reputation and popularity in the Arab world is unprecedented particularly because most of his love and romantic poems that give credit to women are transformed into well known popular songs performed by famous Arab singers. Qabbani died in 1998 leaving behind him large legacies of books, anthologies, songs, prose works and a history of struggle against all forms of oppression in the Arab world. His unequal poetic works stand as a testimony of a great poet and a modern warrior. Qabbaniis undoubtedly one of the most famous and prominent poets in the entire history of Arabic literature from the PreIslamic era until the modern times.

viii Saddik Gohar. "The Protest Poetry of Muhamad AlFayturi and Langston Hughes". Studies in Islam and the Middle East Vol.4.1 (2007): 1-11.

${ }^{i x}$ In May 1967 Arab countries particularly Egypt, Syria and Jordan mobilized their forces in addition to an extensive media campaign against Israel threatening to drive Israel to the sea. The fear of an imminent attack as well as the withdrawal of the United Nations emergency forces located on the Egyptian-Israel borders due to Egyptian orders led the Israel government to believe that an Arab military assault war imminent. Things became worse when Jamal Abdul-Nasser, the Egyptian president at that time, announced the blockade of the straits of Tiran preventing Israel to have access to its Eilat port on the Gulf of Aqaba. Mutual defense pacts were signed between Egypt on one hand and Jordan and Iraq on the other. Anti-Israeli incendiary Arab rhetoric and daily threats in Arab media terrified the Israeli community and contributed to the pressures to go to war. The Arab call of a war of total destruction against Israel ended with their defeat. In six days and due to a successful and preemptive military operation led by the Israeli air forces on the fifth of July 1967 , the Israeli army was able to capture the Sinai peninsula, the Golan Heights, the West Bank including Eastern Jerusalem in addition to Gaza strip. The war which started on the fifth of June and ended on the tenth of June changed the standards of power in the Middle East forever.

${ }^{x}$ Antara, the black son of a noble tribesman from Arabia was subjugated to different forms of humiliation including the betrayal of his father who denies his paternity and considers him as a slave living in his 
household. As a young man, Antara was famous for his poetic talent and war adventures. He was a talented poet who composed famous epics dealing with tribal life. He was also a great warrior who defended his tribe against the invasions of the enemies. Due to his kindness and herois m, Abla, the most beautiful girl of the noble tribe of Abs, fell in love with him in spite of being a black slave. xi Saddik Gohar. "Rethinking WatariyyatLayliyya / Night Strings." Rupkatha Journal on Interdisciplinary Studies in Humanities Vol.3.4 (2011): 443-480.

xii Saddik Gohar."The Use of T.S. Eliot's Literary Traditions in Contemporary Arabic Poetry". In Chewing Over the West: Occidental Narratives in Non-Western Readings, Ed. Doris Jedamski. New York: Rodopi, 2009. 127-160.

${ }^{x i i i}$ All the extracts and citations from The Complete Political Works of Qabbani (1993) are translated by the author of the paper. See Saddik Gohar , Selections from Twentieth-Century Arabic Poetry . Cairo :Oyun Press , 2001.

${ }^{\mathrm{xiv}}$ Qabbani refers here to the historical hostility between two rival poets representing tribal conflicts in ancient Arab culture. The first one is Abu HerzahJareer (653732) a poet from the Kulayb tribe who lived in Yamama in the Arabian Peninsula. Jareer was a talented poet but he descended from a very poor family and a modest social background. The second poet was titledal-Farazdaq and his name was Homam Bin Ghaleb al-Tamimi (658-728) who came from noble origins and lived in Najd in the Arabian Peninsula. During the Umayyad era ,Jareer and al-Farazdaq exchanged satirical poems attacking and lampooning each other. For fifty years, each one of them composed tens of poems glorifying the traditions and glorious contributions of his own tribe. As the speaking voices of their tribal communities, they mutually attack each other's tribe using obscene rhetoric and humiliating polemics .

${ }^{\mathrm{xv}}$ Al-Khansa' bent $\operatorname{Umr}(575-664)$ is the title given to Tumadder al-Sulmeyya ( from the BanuSulaym Tribes) the famous Arabian female poet who lived in preIslamic (Jaheliyya - age of ignorance ) and early Islamic eras . The word (al-Khansa') in ancient Arab culture signifies the wide / beautiful eyes of wild cows. The title is also associated with women who have beautiful noses. Al-Khansa' was famous for her eloquent poetry particularly her elegies written in lamentation of her two brothers who were killed in tribal conflicts. She deeply loved her brother Sakher - in particular- because of his kindness and generosity. After his murder she wrote the most memorable elegies - dedicated to him - in the history of Arabic literature. Unfortunately, al-Khansaa lost her eye-sight completely and became blind as a result of excessive weeping and sadness in the aftermath of the murder of her brother.

${ }^{\mathrm{x} v \mathrm{~J} J o h a}$, is a popular folklore figure, a symbol of idiocy and cunningness at the same time. This character appears in different cultures under a variety of names. He appears in different shapes in Turkish , Kurdish ,
Armenian, Central Asian and East-European cultures The Arabian Joha was associated with the character of Abu al-GhusnDojayn al-Fazari who lived in the seventhcentury during the Umayyad dynasty . The figure of Joha and his donkey are very famous in Arabic culture. Joha's jokes and anecdotes which reveal his criticism of different aspects of the socio-political life in Arab-Islamic community along history are part and parcel of Arabic cultural traditions.

xvii Saddik Gohar. "Rewriting Islamic History in Contemporary Arabic Poetry". Romano-Arabica Vol. 8 (2011): 54-93.

xviii Saddik Gohar. "Frontiers of Violence and Fear: A Study of Native American and Palestinian Intifada Poetry". Nebula: A Journal of Multidisciplinary Scholarship Vol.2.3 (2005): 34-69.

${ }^{x i x} \mathrm{Abu}$ Tammam is the title of the Arab poet Habib Ibn Aws Ibn al-Harith al-Ta'ee (796-843) who descends from Christian origins. His father was a Christian from Horan in Syria and he had a tavern in Damascus . After the conversion of Abu Tammam to Islam, he affiliated himself with the Ta'ee tribe. Abu Tammam started his life as a tailor in Damascus, then he settled in Homos city - in Syria- where he became a famous poet. His alHamasa anthology brought him reputation and wealth . One of his famous poems is addressed to the Abbasid caliph al-Muta'sem after his military victory over the army of the Byzantine empire in (838) at the battle of Amorium, a city in Phrygia, Asia Minor, founded during the Hellenistic period. Its ruins are located near the village of Hisarkoy, Turkey. The city flourished under the reign of the local emperor Michael II . Its strategic location in central Asia Minor made it a frequent target for successive Arab invasions after the Arab conquest of the Levant. It was attacked in 644 and occupied in 646 but regained later. Sieges were laid around the city in 716 and 796 but it fell only in 838 during the offensive led by caliph al-Muta'sem. In 1116 Emperor A.I. Komnenos defeated the Seljuks who tried to re-occupy Amorium.

${ }^{x x}$ Umar (Umar Ibn al-Khattab) was the second Muslim caliph after the death of prophet Mohamed. He was famous for achieving justice and taking the rights of the poor from the rich. He lived a life of simplicity and austerity and he was an embodiment of power and forgiveness. On the other hand, Ali (Ali Ibn Abi Taleb) the fourth caliph, and a key figure in Islamic history was known for his wisdom, self-denial and resistance against oppression. He was the prophet's cousin and son in law who slept in his bed at the night of his escape from the infidels of Mecca to establish the Muslimstate in Medina. Ali was considered as a hero -since his childhoodbecause he jeopardized his life to death in order to save the prophet.

xxi Saddik Gohar."Subverting the History of Slavery and Colonization". Western Journal of Black Studies. Vol.1 (2008): 16-29. 
xxii Saddik Gohar."Exile and Revolt: Arab and AfroAmerican Poets in Dialogue”. In Creativity in Exile, Ed. M. Hanne. New York: Rodopi, 2004. 159-181.

xxiii Saddik Gohar. "The Poetics of Resistance". International Journal of Arabic and English Studies Vol.7 (2006): 5-28.

xxiv Saddik Gohar. "The Protest Poetry of Muhamad AlFayturi and Langston Hughes". Studies in Islam and the Middle East Vol.4.1 (2007): 1-11.

${ }^{\mathrm{xx}}{ }^{\mathrm{T}}$ The massacre of Karbala' which took place forty-eight years after the death of Prophet Muhammad could be traced back to the antagonism between Ali, Prophet Muhammad's cousin and Moawiyya, his political rival and the founder of the Umayyad Dynasty. When Othman, the third Muslim Caliph was mysteriously assassinated, Ali became the Caliph of the Muslim people but the murder of Othman and the inability to identify his killers triggered a conflict between Ali and Moawiyya, the governor of Damascus, because Ali believed that Moawiyya was aware of the identities of the Caliph's assasins. After the murder of Ali, Moawiyya became the Caliph and Ali's family accepted him as the leader of the Muslim nation on the condition that Moawiyya's successor should be selected by the Muslim people through election. Nevertheless, Moawiyya violated the agreement and appointed his corrupt son Yazid as a future Caliph. After the death of Moawiyya, Yazid became the Caliph of the Muslim people. Some prominent figures from Makka expressed rebellion against Yazid in addition to the people of Iraq who sent to Al-Hussein, inviting him to come from the Arabian Peninsula to establish a separatist Islamic State in their country. In response to their invitation Al-Hussein and about thirty of his followers including his family came from Makka to Iraq riding horses and camels. When Al-Hussein and his company arrived at Karbala', southern of Iraq, the Iraqis betrayed him because they were intimidated by the powerful army of AbullahIbnZeyyad, who was appointed as the governor of Iraq by Yazid. After being besieged and prevented from food and water in Karbala', AlHussein was given two options, either to acknowledge Yazid as the Caliph of the Muslim people or face his army, more than thirty thousand soldiers. Al-Hussein appealed to the leaders of the enemy army to allow him to return to Makka in peace, but his appeal was turned down. Determined not to surrender or acknowledge Yazid as the Caliph, Al-Hussein's decision to fight to the end was a suicidal mission. After being killed, the dead bodies of Al-Hussein, his families and followers were mutilated and his head was cut off and fixed on a spear and carried to be exhibited in Yazid's palace in Damascus.

xxvi It is noteworthy to argue that the phrase "cities of salt" is quoted afterwards by the famous Saudi novelist AbdulRahman Munif and used as a title for a sequence of novels depicting the miserable reality of the Arab world

xxvii Saddik Gohar. "The Discourse of Exile and Displacement in Arabic and Palestinian Poetry". Hyphen: An International Journal of Interdisciplinary
Studies in Literature, Art and Culture Vol. 2 (2011): 3041.

xxviii Saddik Gohar. "Toward a Dialogue between the Arab World and the West: The City Analogy in the Poetry of T.S. Eliot and Badr Shaker Al-Sayyab". Journal of Middle Eastern and North African Intellectual and Cultural Studies Vol. 4 (2006):43-67.

xxix Saddik Gohar."The Use of Eliot's Modernism in AlSayyab's City Poetry". Comparative Civilizations Review Vol. 56 (2007): 40-55

$\operatorname{xxx}$ The allusion here refers to the assassination of Prophet Mohamed's grandson, al-Hussain .The brutal and ritualistic murder of al-Hussain, the prophet's grandson, by the followers of the Umayyad caliph , in Karbala', during the early Islamic era, split the Muslim nations into two parts, the Shiites and the Sunnis. The battle of Karbala' where al-Hussain was assassinated for vicious political reasons, is frequently used as a symbol of ArabArab conflicts while al-Hussain is immortalized as a mythic hero who sacrifices his blood for the sake of his principles.

xxxi Saddik Gohar. "Re-historicizing the Six-Day War: The Counter Poetics of Nizar Qabbani". SKASE Journal of Literary Studies Vol.3.1- (2011): 97-116. 